\title{
RELACIÓN ENTRE DERECHO COMUNITARIO Y CONSTITUCIÓN
}

\author{
MARÍA BALLESTER CARDELL \\ Profesora Ayudante de Derecho Constitucional \\ Universidad de las Islas Baleares
}




\section{SUMARIO}

I. La primacía y la aplicación del Derecho comunitario en España. A) Introducción. B) La Constitución como norma jurídica. C) La aplicación directa de la Constitución. D) El principio de supremacía de la Constitución. E) La Constitución Española y el Derecho comunitario europeo. Especial referencia al artículo 93 de la Constitución Española. II. CONFLICTO ENTRE NORMA COMUNITARIA Y CONSTITUCIÓN. A) Relación entre la ley interna y el Derecho comunitario. B) Oposición entre Tratados originarios y Constitución Española. C) Oposición entre normas del Derecho derivado y de la Constitución. En especial, la relación entre el Derecho comunitario y los derechos fundamentales nacionales. III. DoctRINA DEL TRIBUNAL DE LUXEMburgo. IV. Jurisprudencia del Tribunal Constitucional Español. A) Sentencia del Tribunal Constitucional 28/1991, de 14 de febrero. B) Sentencia del Tribunal Constitucional 64/1991, de 22 de marzo. C) Sentencia del Tribunal Constitucional 180/1993, de 31 de mayo. V. ConcLusiones. 


\title{
RELACIÓN ENTRE DERECHO COMUNITARIO Y CONSTITUCIÓN
}

POR

\author{
MARÍA BALLESTER CARDELL \\ Profesora Ayudante de Derecho Constitucional \\ Universidad de las Islas Baleares
}

\section{LA PRIMACÍA Y LA APLICACIÓN DEL DERECHO COMUNITARIO EN ESPAÑA}

\section{A) Introducción}

La primacía y la eficacia directa del Derecho comunitario en España significa una importante "revolución" en el sistema de fuentes de nuestro ordenamiento jurídico. En efecto, el constituyente ordenó un conjunto normativo de acuerdo con el principio de jerarquía (en relación a normas que regulan la misma materia) y el principio de competencia (que relaciona las disposiciones normativas que tratan cuestiones o materias distintas), con la Constitución en la cima del ordenamiento, como norma jurídica directamente vinculante, aun cuando sus diversos preceptos tienen un distinto nivel de eficacia según su particular naturaleza jurídica. Además, prevé una distribución horizontal del poder (atendiendo al principio de separación de poderes) y una división vertical de competencias (en favor de las comunidades autónomas), perfilando un sistema de organización y funcionamiento estructural que permita una optimización de los recursos y asegure la salvaguarda y garantía de los derechos fundamentales de los ciudadanos. Ahora bien, no puede negarse tampoco que el constituyente tenía puesta la mirada en Europa, a lo cual responde al articulo 93 de la 
Constitución Española, auténtico referente en el cambio estructural antes señalado'.

La culminación del proceso de adhesión afecta no sólo al concepto de soberanía, sino que significa una reestructuración del sistema de fuentes del Derecho, que, con la Constitución a la cabeza, debe incorporar el ordenamiento comunitario como Derecho propio. Pues, los Tratados Constitutivos forman parte del Derecho interno desde el momento que determinó el propio Tratado de Adhesión -o sea, desde el 1 de enero de 1986- y la aceptación de tales Tratados significa la recepción del Derecho derivado con la obligatoriedad y eficacia establecida en los Tratados ${ }^{2}$. Dicho con otras palabras, la condición de Estado miembro supone la configuración de un "ordenamiento jurídico cuyo parámetro de legalidad no es ya sólo la propia Constitución Española sino el "pacto común" expresado en el Derecho comunitario europeo, originario y derivado» ${ }^{3}$.

Esta última cuestión provocará, lógicamente, tensiones o problemas en cuanto a la aplicación de la norma correcta o adecuada en cada caso. Se plantean dificultades en los casos de colisión entre el Derecho comunitario y el Derecho interno, conflictos que cuando enfrenten la Constitución con el ordenamiento de la Comunidad tendrán compleja solución, dado el valor normativo supremo de la primera y la primacía y eficacia directa del segundo.

\section{B) La Constitución como norma jurídica}

Hablar de la Constitución como norma jurídica significa reconocer su valor y eficacia inmediata como fuente de Derecho, como elemento del que emana el Derecho. La Constitución nace como una norma fundamental de organización para asegurar la libertad individual. No hay que olvidar, en este sentido, que los textos constitucionales surgen como un pacto para hacer efectivo un control sobre el poder

1 Cfr. Abellan Honrubia, Victoria y Vilà Costa, Blanca: Lecciones de Derecho Comunitario Europeo, Ariel, Barcelona, 1995, pág. 133. Califica el artículo 93 como "la base constitucional suficiente" que legitima jurídicamente las obligaciones estructurales del Estado Español tras la integración en las Comunidades Europeas.

2 Cfr. MAngas MARTín, Araceli, en la obra colectiva: Instituciones de Derecho Internacional Público (coordinada por Manuel DIEZ DE VELASCO), Tecnos, Madrid, vol. I, págs. 203-204.

3 Cfr. Abellán Honrubia, Victoria y Vilà Costa, Blanca: Lecciones de Derecho..., op. cit., pág. 133. 
del Estado, lo cual tiene como objetivo último garantizar los derechos fundamentales ${ }^{4}$. Este acuerdo o declaración de voluntad, lógicamente, nace con el propósito de vincular y obligar a todos. Cierto es que esta finalidad no se consigue al comienzo de nuestra historia constitucional, ni siquiera en las Constituciones extranjeras de la primera época, pues aunque no podían ser entendidas como un conjunto de simples principios programáticos, tampoco proclamaban formalmente su carácter normativo ${ }^{5}$. Fue en Estados Unidos, por vía jurisprudencial, a través de la conocida Sentencia del Tribunal Supremo norteamericano en el caso Marbuy versus Madison, donde se reconoce por vez primera el valor jurídico-normativo y con ello se consagra la idea de su vinculación y eficacia como norma suprema del ordenamiento. La generalización de este principio en Europa se produce en pleno período de entreguerras, aun cuando desde principios de siglo emerge la idea de la Constitución como valor jurídico superior del ordenamiento.

La Constitución Española de 1978, rompiendo con la tradición de nuestro constitucionalismo salvo el breve episodio de la Constitución republicana de 1931, se autoproclama como norma jurídica, al establecer el sometimiento de los ciudadanos y de los poderes públicos a la Constitución y al resto del ordenamiento jurídico (art. 9.1 de la Constitución Española). A la vista de lo cual, el Texto Constitucional deviene una regla de valor normativo de aplicación inmediata. Por tanto, tiene los caracteres de capacidad vinculante, obligatoriedad y coerción, elementos típicos de las auténticas normas jurídicas ${ }^{6}$. Este principio se proclama también, muy especialmente, en materia de derechos y libertades en el artículo 53.1 CE ("Los derechos y libertades reconocidos en el capítulo II del presente título vinculan a todos los poderes públi-

4 Cfr. Espín Templado, Eduardo (en el libro colectivo): Derecho Constitucional, Tirant lo Blanch, Valencia, 1991, vol. l, pág. 39.

5 Sin embargo, tal como señala el profesor Isidre Molas Batllori (Derecho Constitucional, Tecnos, Madrid, 1988, pág. 207), "sería erróneo suponer que la progresiva consolidación de los Estados liberales en Europa hubiera podido realizarse a partir de la idea que la Constitución no era una norma vinculante, y que se limitaba a ser una declaración genérica de carácter meramente programático".

6 Cfr., entre otros, De Esteban, Jorge y González-TreviJano, Pedro J.: Curso de Derecho Constitucional Español, Servicio de Publicaciones de la Facultad de Derecho, Universidad Complutense, Madrid, 1992, vol. I, pág. 199; Aparicio Pérez, Miguel Ángel: Temes de Dret Constitucional, Publicacions de la Universitat de Barcelona, Barcelona, 1996, vol. I, pág. 524. Gomez SÁnchez, Yolanda: Introducción al régimen constitucional español, Servicio de Publicaciones de la Facultad de Derecho, Univeridad Complutense, Madrid, 1997, pág. 283; Espin TeMPLADO, Eduardo: Derecho..., op. cit., pág. 41. 
(cos»), aunque, como veremos más adelante, no todos ellos cuentan con el mismo nivel de eficacia.

La vinculación de los ciudadanos y de los poderes públicos a la Constitución significa, por un lado, que se configura como un límite al poder del Estado al regular la actividad de los poderes públicos, procurando garantizar o salvaguardar los derechos y libertades de los ciudadanos en el caso de extralimitación de sus atribuciones; de forma que, si un poder público se excediera de los límites fijados por la Constitución, su actuación devendría ilegítima, pues caracería de base y fundamentación en Derecho ${ }^{7}$. Sin embargo, y en segundo lugar, tal protección no desvincula a los ciudadanos de su acatamiento, los cuales están obligados a asumir los mandatos constitucionales. Así lo ha entendido también la jurisprudencia del Tribunal Constitucional. La Sentencia 16/1982, de 28 de abril, establece que:

"Conviene no olvidar nunca que la Constitución, lejos de ser un mero catálogo de principios de no inmediata vinculación y de no inmediato cumplimiento hasta que sean objeto de desarrollo por vía legal, es una norma jurídica, la norma suprema de nuestro ordenamiento, y en cuanto tal, tanto los ciudadanos como todos los poderes públicos $y$, por consiguiente, también los jueces y magistrados integrantes del poder judicial están sujetos a ellan ${ }^{8}$.

Ahora bien, la Sentencia 101/1983, de 18 de noviembre, establece un diferente nivel de vinculación de la Constitución en relación a los particulares y a los poderes públicos, pues

7 Cfr. López Guerra, Luis: Introducción al Derecho Constitucional, Tirant lo Blanch, Valencia, 1994, pág. 53.

8 Esta doctrina del Tribunal Constitucional ha sido firme y rotunda desde las más tempranas sentencias. Así, la Sentencia de 15 de junio de 1981 califica la Constitución como una "norma suprema directamente aplicable». La Sentencia 101/1983, de 18 de noviembre, señala que «la sujeción a la Constitución es una consecuencia obligada de su carácter de norma supreman. Podriamos continuar con las citas que siguen estas líneas de interpretación, aunque no creemos que sea necesario insistir más en este principio generalmente aceptado. La seguridad y la firmeza que ha caracterizado la doctrina jurisprudencial contrasta, sin embargo, con las iniciales reticencias del Tribunal Supremo a aceptar el carácter normativo de la Constitución, pues consideraba necesaria la existencia de leyes de desarrollo de los preceptos constitucionales para aceptar su invocación ante los tribunales. No obstante, tras un giro radical en sus planteamientos, también ha aceptado la aplicabilidad inmediata de la Constitución, dado su carácter preeminente sobre cualquier otra disposición. 
"mientras los primeros tienen un deber general negativo de abstenerse de cualquier actuación que vulnere la Constitución, sin perjuicio de los supuestos en que la misma establece deberes positivos, los titulares de los poderes públicos tienen además un deber general positivo de realizar sus funciones de acuerdo con la Constitución...".

\section{C) La aplicación directa de la Constitución}

La cuestión sobre los diferentes grados de vinculación de los preceptos constitucionales también puede plantearse en otro nivel, pues el carácter normativo de la Constitución no significa que todos y cada uno de sus artículos presenten la misma eficacia ${ }^{9}$, lo cual se hace particularmente evidente en materia de derechos constitucionales que, en ocasiones, requerirán determinadas condiciones, que pasan normalmente por la intervención del legislador. En efecto, las diversas normas constitucionales tienen distinta vinculación jurídica, o sea, son manifiestamente heterogéneas en cuanto a su eficacia inmediata. Distinguiremos estructuralmente, la parte dogmática de la Constitución de su parte orgánica para tratar la cuestión de la aplicación directa o mediata de los preceptos constitucionales.

La parte dogmática, integrada, básicamente por el título preliminar y el título primero - "De los derechos y deberes fundamentales»-es la que presenta una mayor diversidad en cuanto a su eficacia normativa. Así, por un lado, el título preliminar establece los valores fundamentales o "principios generales» ${ }^{10}$. Los principios del orden jurídicopolítico, proclamados especialmente en los artículos 1.1 y 9.3 , inspiran e impregnan el resto de los preceptos constitucionales $y$, por tanto, tienen un valor interpretativo. No obstante, al margen de tales disposiciones, encontramos en este título "auténticas normas jurídicas, con estructura lógica de tales y, por consiguiente, de directa aplicación y vigencia, como la declaración del castellano como lengua oficial del Es-

9 En palabras de Miguel Ángel Aparicio Pérez (Temes de Dret..., op. cit., vol. I, pág. 525), a pesar de que se predique el carácter normativo de la Constitución no todos sus preceptos tienen el mismo alcance ni su misma eficacia jurídica. Con criterio análogo, cfr. De Esteban, Jorge y González-Trevijano, Pedro J.: Curso de Derecho..., op. cit., pág. 203.

10 Tal era la denominación utilizada por el Anteproyecto de Constitución publicado en el Boletín Oficial de las Cortes el 5 de enero de 1978. 
tado, la descripción de la bandera española o la capitalidad del Estado en Madrid»".

En segundo lugar, el título primero establece la relación de derechos de los ciudadanos, divididos en dos categorías distintas: los derechos fundamentales y libertades públicas son directamente vinculantes, sin necesidad de desarrollo legislativo ulterior, al igual que los deberes de los ciudadanos, tal como señaló tempranamente la doctrina del Tribunal Constitucional ${ }^{12}$. El Alto Tribunal entendió que los derechos y libertades del capitulo II del Título I son origen inmediato de derechos y obligaciones, y que uen todo caso sus principios son de aplicación inmediata». En definitiva, el capítulo Il goza de máxima vinculación, pues los derechos en él proclamados permiten exigir de los poderes públicos bien la restitución de un derecho vulnerado, bien hacer efectivo un determinado derecho, independientemente de su desarrollo normativo posterior. Por otro lado, los derechos del capitulo III -en terminología constitucional los «principios rectores de la política social y económica»-deben inspirar la actuación de los poderes públicos, aun cuando tan sólo podrán ser invocados ante los tribunales en base a la legislación de desarrollo (art. 53.3 CE). Tales principios rectores vinculan mediatamente a los poderes públicos, pues el legislador debe tenerlos presentes como fuentes de su labor, el ejecutivo debe inspirarse en ellos para llevar a cabo la dirección política y los jueces o tribunales deben aplicarlos, aunque dicha aplicación será limitada en tanto no se haya desarrollado una legislación complementaria. No podemos concluir el análisis del Título I sin aludir a dos de sus preceptos perfectamente incardinables en la categoría de principios o valores fundamentales del ordenamiento constitucional: el artículo 10.1, cuya referencia es obligada en relación a cualquier precepto constitucional; y el artículo 14, que proclama el principio de igualdad ante la ley. Por tanto, tales disposiciones no tienen eficacia normativa directa, aun cuando impregnan la totalidad de los derechos fundamentales y el resto de los mandatos constitucionales.

Por lo que se refiere al valor normativo de la parte orgánica (títulos II y siguientes) de la Constitución, nuestro análisis será mucho más somero, dado que su contenido, elaborado sobre la base de la separación de poderes y de la distribución territorial del poder, deja lugar a pocas dudas. En efecto, mayoritariamente se ha admitido la eficacia ju-

1 Cfr. Garrido Falla, Fernando: "Título Preliminar" en Comentarios a la Constitución (dirigida por Fernando GaRRIDO Falla), Civitas, Madrid, pág. 21.

12 STC de 8 de junio de 1981 y STC de 15 de junio de 1981. 
rídica directa de las normas que regulan la configuración de los diferentes órganos constitucionales y de las disposiciones atributivas de competencia, las cuales vinculan de modo inmediato a los poderes públicos, sin necesidad de una ley interpuesta ${ }^{13}$.

Concluiremos este punto sobre la aplicabilidad de las normas constitucionales con unos pasajes de la doctrina del Tribunal Constitucional en relación a la vinculación inmediata de los derechos fundamentales, que puede generalizarse al resto de la Constitución. Se trata de la Sentencia 15/1982, de 28 de abril, según la cual:

"Los derechos y libertades fundamentales vinculan a todos los poderes públicos y son origen inmediato de derechos $y$ obligaciones, no meros principios programáticos. Este principio general de aplicabilidad inmediata no tendrá más excepciones que aquellos casos en que así lo disponga la propia Constitución o en que la naturaleza misma de la norma impida considerarla inmediatamente aplicable».

A la vista de lo cual podemos concluir que, en principio, todos los mandatos constitucionales son directamente aplicables, aunque la diversa naturaleza de los mismos puede hacer depender su plena eficacia de su desarrollo por parte del legislador ordinario; si bien, en todo caso, "la aplicabilidad de sus normas vendrá condicionada por el mismo carácter de la norma y por las previsiones expresas que realice la propia Constitución ${ }^{14}$. Ello no significa, ni mucho menos, que exista una jerarquía entre los diversos preceptos de la Constitución, a pesar de que algunos autores admitan la presencia en la Constitución de artículos más importantes unos que otros ${ }^{15}$.

\section{D) El principio de supremacía de la Constitución}

Existen múltiples aspectos en relación a los cuales podríamos plantear el carácter supremo de la Constitución. Desde un punto de vista formal, su origen gestado por el poder constituyente y las espe-

13 Cfr. Fernández Segado, Francisco: El sistema constitucional español, Dykinson, Madrid, págs. 71-72.

${ }_{14}$ Cfr. Molas Batllori, Isidre: Derecho..., op. cit., pág. 211.

15 Cfr. De Esteban, Jorge y González-Trevijano, Pedro J.: Curso de Derecho..., op. cit., vol. I, pág. 204; Oliver Araujo, Joan: "Corona y sexo" en el diario El Mundo, día 23 de noviembre de 1998, pág. 8. 
cialidades del procedimiento de reforma de los preceptos constitucionales. En cuanto a su contenido, la Constitución incluye los valores, principios, derechos, fuentes $y$ organización del ordenamiento jurídico; lo cual, sin duda, la presenta como la norma suprema de un sistema democrático. La concurrencia de estos aspectos generan la aparición de una Constitución que, autoproclamada disposición que vincula a los ciudadanos y a los poderes públicos, se sitúa en la cúspide del ordenamiento jurídico. Sin embargo, el aspecto que más nos interesa destacar es la instauración de un "marco de constitucionalidad" que se convierte en instrumento de garantía del propio régimen constitucional.

La Constitución, en tanto que norma suprema del ordenamiento, establece unos mecanismos de protección y respeto de sus disposiciones. La sujeción de los poderes públicos a la Constitución, que proclama el artículo 9.1, significa que aquéllos deberán adecuar su actuación a los postulados constitucionales y que, en caso contrario, sus actos serán nulos. Especialmente grave es la contravención constitucional por parte del poder legislativo, en la medida que supone una colisión entre el poder constituido donde aparece representada la voluntad popular y el poder constituyente, legitimado igualmente por el cuerpo electoral. Ante tales conflictos, se ha instituido un órgano especial, el Tribunal Constitucional, encargado de controlar la constitucionalidad de las leyes a través de los procesos de constitucionalidad ${ }^{16}$.

Como ya se adelantó al inicio de este epígrafe, el elemento que delimita y establece los parámetros de adecuación de las leyes en el marco constitucional es el denominado "bloque de la constitucionalidad". Sería una ingenuidad pensar que la Constitución, a pesar de su supremacía sobre el resto del ordenamiento, es capaz de contener y proclamar todos los criterios para apreciar la inconstitucionalidad de una disposición normativa. La necesaria limitación y generalidad de la Constitución como norma fundamental que dibuja las directrices de la

16 El proceso de constitucionalidad consiste en un juicio ante el Tribunal Constitucional en el que se compara la Constitución y la ley y que finaliza bien con una sentencia confirmatoria de la constitucionalidad de la ley, bien con una sentencia declaratoria de la inconstitucionalidad de la ley. Existen básicamente tres procesos de inconstitucionalidad destinados a depurar el sistema normativo: el recurso de inconstitucionalidad (art. 161.1.a CE), la cuestión de inconstitucionalidad (art. $163 \mathrm{CE}$ ) y la autocuestión de inconstitucionalidad o cuestión de inconstitucionalidad impropia (art. 55.2 LOTC). Sobre las deficiencias de esta última vía y las posibles vías de solución puede verse el excelente trabajo del profesor Joan OLIVER Araujo titulado: El recurso de amparo, Universitat de les Illes Balears, Palma de Mallorca, 1986, págs. 366-375. 
organización estatal es la principal causa de tal insuficiencia, pero no la única. La complejidad del sistema de distribución del poder entre Estado y comunidades autónomas, y a la amplitud del sistema normativo susceptible de ser impugnado ante el Tribunal Constitucional enfatiza todavía más aquella carencia. A la vista de lo cual, se ha tenido que arbitrar un bloque o canon de constitucionalidad que es el que delimita los parámetros en los que puede moverse una ley sin contravenir el marco constitucional, previsto en el artículo 28 de la Ley Orgánica $2 / 1979$, de 3 de octubre, del Tribunal Constitucional ${ }^{17}$ (en adelante LOTC). La Constitución es, por tanto, insuficiente para dibujar el perfil ideal al que deben ajustarse las normas con rango de ley. Por contra, el bloque de la constitucionalidad comprende, en palabras del profesor Molas, "la Constitución española, los estatutos de autonomía, las leyes previstas en el artículo 150 de la Constitución y, en general, todas las leyes que delimiten las competencias entre Estado y comunidades autónomas o que establezcan la competencia de los órganos que dicten leyes o normas con rango de ley" ${ }^{18}$.

La insuficiencia de la Constitución para abarcar el nivel de constitucionalidad permite plantear la siguiente cuestión: ¿Puede entenderse que la integración en la Unión Europea significa un cambio sustancial en el parámetro de validez de las leyes nacionales en el ámbito constitucional? Dicho con otras palabras, ¿puede el Derecho comunitario ser entendido como un elemento definidor de la adecuación de una ley interna a los dictados constitucionales? Del mismo modo que los estatutos de autonomía, como normas de organización básica de una comunidad autónoma son susceptibles de determinar la posible inconstitucionalidad de una norma, se podría formular la afectación de las leyes internas por parte de las disposi-

17 El artículo 28 de la LOTC indica: «1. Para apreciar la conformidad o disconformidad con la Constitución de una Ley, disposición o acto con fuerza de ley del Estado o de las Comunidades Autónomas, el Tribunal considerará, además de los preceptos constitucionales, las Leyes que, dentro del marco constitucional, se hubieran dictado para delimitar las competencias del Estado y las diferentes comunidades autónomas o para regular o armonizar el ejercicio de las competencias de éstas.

"2. Asimismo, el Tribunal podrá declarar inconstitucionales por infracción del artículo 81 de la Constitución los preceptos de un decreto-ley, decreto legislativo, ley que no haya sido aprobada con el carácter de orgánica o norma legislativa de una comunidad autónoma en el caso de que dichas disposiciones hubieran regulado materias reservadas a ley orgánica o impliquen modificación o derogación de una ley aprobada con tal carácter cualquiera que sea su contenidon.

18 Cfr. Molas Batllori, Isidre: Derecho..., op. cit., pág. 234. 
ciones comunitarias ${ }^{19}$. Sin embargo, entendemos que esta postura no es la más acertada. En primer lugar, porque el Derecho comunitario no es un derecho superior al Derecho interno, sino un conjunto normativo que sustituye al Derecho nacional en los supuestos en los que el Estado ha cedido parte de su soberanía. En segundo lugar, por vía de interpretación analógica, podemos utilizar los argumentos del Tribunal Constitucional para reafirmar que la integración de España en la Unión Europea no ha significado una alteración del "canon de validez en los procesos de amparo ni el carácter del Tribunal Constitucional como intérprete supremo de la Constitución ${ }^{20}$. En efecto, si la instauración del conjunto normativo comunitario no significa alteración de las causas $y$ los requisitos para interponer recurso de amparo, tampoco ha de afectar el bloque de la constitucionalidad que pueda permitir la declaración de inconstitucional de una ley interna por ser contraria a la Constitución. $Y$, en tercer lugar, porque los conflictos entre la norma nacional $y$ el Derecho comunitario tiene sus propios cauces de solución que no pasan por la interposición del recurso de inconstitucionalidad, sino por la aplicación por parte del juez ordinario de la disposición comunitaria y en caso de duda plantear el reenvío prejudicial (art. 177 Tratado CEE). Insistiremos sobre todas estas cuestiones más adelante. Por de pronto, lo que nos interesa destacar es la no incursión del Derecho comunitario en el marco de la constitucionalidad y la competencia absoluta del Tribunal Constitucional para declarar nula de pleno derecho una norma por contravenir el parámetro de validez constitucional.

\section{E) La Constitución española y el Derecho comunitario europeo. Especial referencia al artículo 93 de la Constitución Española}

La adhesión de España a las Comunidades Europeas cuenta con el marco jurídico del artículo 93 de la Constitución ${ }^{21}$. Este precepto con-

19 En cierta medida, ésta es la postura de la doctrina del Tribunal de Justicia de la Comunidad Europea al defender el carácter preferente del Derecho comunitario sobre el Derecho interno. Cfr. Sentencia del Tribunal de Justicia de 15 de julio de 1964, asunto 6/64, Costa c/ENEL, Rec. 1964, Sentencia del Tribunal de Justicia de 13 de julio de 1972, asunto 48/71, Comisión c/ltalia, Sentencia del Tribunal de Justicia de 15 de octubre de 1986, asunto 168/85, Comisión c/ltalia y Sentencia del Tribunal de Justicia de 9 de marzo de 1978, asunto 106/77, Administración de Hacienda del Estado c/Simmenthal.

20 STC 64/1991, 22 de marzo, fundamento jurídico 4-a).

21 Dicho artículo señala textualmente: «Mediante ley orgánica se podrá autorizar la celebración de Tratados por los que se atribuya a una organización o ins- 
tiene tres partes bien distintas, aun cuando son absolutamente complementarias. En primer lugar, es un instrumento de autorización de un determinado tipo de tratado. En segundo lugar, es una regla que transfiere determinadas cuotas de soberanía en favor de instancias que conforman una organización supranacional. Por otro lado, se instaura como sistema de garantía la inclusión de los tratados y de los actos de las Instituciones supranacionales en el derecho interno ${ }^{22}$.

En cuanto mecanismo procedimental, el artículo 93 señala el elemento formal que debe revestir el instrumento de conclusión del tratado de integración del Estado Español en una organización supranacional a la que se atribuya el ejercicio de competencias derivadas de la Constitución. En particular, la autorización de tales Tratados debe hacerse mediante ley orgánica, categoría normativa que ocupa una posición central en el sistema constitucional de fuentes del Derecho. El sometimiento de dicha autorización a la rigidez procedimental de las leyes orgánicas ${ }^{23}$, corre parejo a la transcendencia de sus efectos: el Estado se despoja del ejercicio de ciertas competencias en favor de la organización supranacional, lo cual afecta, sin duda, a la propia estructura y organización estatal interna. No obstante, parte de la doctrina ha mostrado su disconformidad con este "quórum tan exiguo", que está muy lejano de «los tres quintos de la Cámara única griega, exigidos por el artículo 28.2 de su Constitución, los cinco sextos del Folketing que establece el artículo 20.2 de la danesa, o los dos tercios de votos de ambas cámaras de los artículos 62 y 63 de la holandesan ${ }^{24}$.

En aplicación de este precepto, las Cortes Generales han aprobado las siguientes leyes orgánicas: la Ley Orgánica 10/1985, de 2 de

titución internacional el ejercicio de competencias derivadas de la Constitución. Corresponde a las Cortes Generales o al Gobierno, según los casos, la garantía del cumplimiento de estos Tratados y de las resoluciones emanadas de los organismos internacionales o supranacionales titulares de la cesión".

22 Este triple contenido ha sido recordado por la Sentencia del Tribunal Constitucional $28 / 1881$, de 14 de febrero.

23 Recordemos que el artículo 154 del Reglamento del Congreso de los Diputados está redactado con el siguiente tenor: «la celebración de Tratados por los que se atribuya a una organización o institución internacionales el ejercicio de competencias derivadas de la Constitución requerirá la previa aprobación por las Cortes de una Ley Orgánica de autorización, que se tramitará conforme a lo establecido en el presente Reglamento para las leyes de este caráctern. Y según el artículo $81.2 \mathrm{CE}$ : “la aprobación, modificación o derogación de las leyes orgánicas exigirá mayoría absoluta del Congreso en una votación final sobre el conjunto del proyecto".

24 Cfr. Ruiz Robledo, Agustín: «El ordenamiento jurídico europeo y el sistema de fuentes español», Revista de Derecho Político, núm. 32, 1991, pág. 37. 
agosto, que autorizó la ratificación del Tratado relativo a la adhesión de España a las Comunidades Europeas; la Ley Orgánica 4/1986, de 26 de noviembre, que autorizó la ratificación del Acta Única Europea; la Ley Orgánica 10/1992, de 28 de diciembre, que autorizó la ratificación por el Estado español del Tratado de la Unión Europea (tras un control previo de constitucionalidad del Tratado, emitido por el Tribunal Constitucional en la Declaración de 1 de julio de 1992); la Ley Orgánica 20/1994, de 29 de diciembre, que autorizó la ratificación del Tratado de Adhesión de Austria, Finlandia y Suecia a la Unión Europea, y la reciente Ley Orgánica 9/1998, de 16 de diciembre, por la que se autoriza la ratificación por España del Tratado de Amsterdam.

Por lo que se refiere al aspecto material derivado del artículo 93, se posibilita un mecanismo de cesión del ejercicio de competencias constitucionales. Lo cual significa que el Estado dejará de ser competente sobre determinadas materias y pasaran a ser gestionadas por la organización supranacional. Tal como señala la mayoría de la doctrina, «no existe más que una atribución del "ejercicio" de competencias soberanas ${ }^{25}$, de forma que la titularidad corresponde siempre al Estado nacional. Ahora bien, antes de autorizar la celebración de acuerdos internacionales de este tipo, para evitar la confluencia de situaciones "incómodas", se prevé la posibilidad de confrontar aquéllos con la Constitución en aras a determinar la existencia de una eventual colisión entre ambos instrumentos ${ }^{26}$. En efecto, «la celebración de un tratado internacional que contenga estipulaciones contrarias a la Constitución exigirá la previa revisión constitucional», según dispone el artículo $95.1 \mathrm{CE}$. Por lo tanto, el artículo 93 no puede amparar una modificación implícita de los preceptos constitucionales, ni puede utilizarse como instrumento para contrariar o rectificar mandatos o prohibiciones contenidos en la Norma Fundamental, tal como se desprende la Declaración del Tribunal Constitucional de 1 de julio de 1992, previa a la ratificación del Tratado de Maastricht ${ }^{27}$.

25 Cfr., por todos, Abellán Honrubia, Victoria y ViLA Costa, Blanca: Lecciones de Derecho..., op. cit., pág. 133.

${ }^{26}$ Cfr. infra Capítulo II, apartado B) Oposición entre Tratados originarios y Constitución Española.

${ }^{27}$ No podemos olvidar que se habian oído voces defendiendo el principio de que un tratado internacional nunca puede ser inconstitucional, pues las eventuales contradicciones entre ellos y la Constitución deben interpretarse como una reforma de ésta a partir de preceptos constitucionales. Así aparece recogido en la obra colectiva de BAStida, Francisco J.; VARELA, Joaquín y Requejo, Juan Luis: Derecho Constitucional. Cuestionario Comentado, l, Ariel, Barcelona, 1992, pág. 143. 
En cuanto al último aspecto del artículo 93 -garantía de cumplimiento de las obligaciones comunitarias internacionales derivadas de este tipo de Tratados y de los actos de las Instituciones comunitarias-, la integración de un Estado en la organización comunitaria europea pasa por aceptar como propio el ordenamiento de la Unión Europea ${ }^{28}$. Por tanto, el sistema de fuentes del derecho se ha visto alterado sustancialmente ${ }^{29}$, en la medida en que, el recorte de determinadas competencias en relación a ciertas materias, se combina con la inclusión del Derecho originario (tratados) y derivado (actos de las Instituciones) de la Unión Europea en nuestro ordenamiento, con sus correspondientes garantías y consecuencias.

La Constitución regula de forma fragmentaria y confusa el sistema de garantías del cumplimiento de las obligaciones internacionales de los Tratados de atribución de competencias emanadas de la Constitución y de las disposiciones normativas emanadas de las organizaciones supranacionales por ellos creados. En efecto, el artículo 93 sólo alude a la intervención de las Cortes o el Gobierno, "según los casos", para asegurar el cumplimiento de los intereses a que responde la firma del Tratado de Adhesión, cuando no cabe duda de que la intervención de los jueces es fundamental para asegurar la aplicación del Derecho comunitario (artículo 177 del Tratado Constitutivo de la CEE). Sea como fuere, la autonomía y especificidad del Derecho comunitario contrasta con sus propias limitaciones, pues requiere de la colaboración activa de los Estados miembros para tener plena eficacia. En virtud del mandato constitucional expreso, serán las Cortes y el Gobierno de la Nación las instancias que deban asegurar el cumplimiento de una norma comunitaria que afecte a una competencia estatal y se deberán tener en cuenta las prerrogativas de las Cortes y las materias y el alcance de la competencia reglamentaria del Gobierno para decantar la opción en cada caso.

Ahora bien, no podemos olvidar que el Estado español distribuye territorialmente su poder en las distintas Comunidades autónomas,

28 Cfr. Molas BatLloRI, Isidre: Derecho..., op. cit., pág. 273. También se pronuncian en este sentido Paz ANDRÉs SÁenz de SANTA MARIA (en la obra colectiva Introducción al Derecho de la Unión Europea, Eurolex, Madrid, 1996, pág. 384), Victoria Abellán Honkubia y Blanca Vilà Costa (Lecciones de Derecho..., op. cit., pág. 133 CE).

29 Según Paz Andrés SAEnz de SANTA María (en la obra colectiva Introducción al Derecho..., op. cit., pág. 385), "el artículo $93 \mathrm{CE}$ es la norma representativa de una Constitución abierta al ordenamiento internacional, que posibilita la integración en el sistema de fuentes interno de la producción normativa de órganos no propiamente constitucionales, sino integrantes del marco institucional único o comunitarion. 
con lo cual se plantea la posible aplicación del Derecho comunitario por parte de aquellas entidades territoriales descentralizadas, en relación a materias cuya competencia le corresponda en virtud de su estatuto de autonomía $a^{30}$. Aunque no podemos extendernos en esta trascendente cuestión, conviene hacer una referencia, por breve que ésta sea. El silencio del constituyente en este punto ha sido suplido por los pronunciamientos del Tribunal Constitucional. En la Sentencia de 28 de mayo de 1992 admite que la competencia estatal en materia de coordinación general de la economía del país no es obstáculo para admitir la intervención de las comunidades autónomas en operaciones de gestión. Por su parte, en la Sentencia de 29 de octubre de 1992, resolviendo un recurso del Gobierno central contra una disposición de la Generalitat Catalana de ejecución de una directiva sobre residuos industriales, el Alto Tribunal admite que le corresponde a la comunidad autónoma. En este mismo sentido, la Sentencia 313/1994, de 14 de noviembre, señala que el control de las características sanitarias y de seguridad de los productos industriales no supone regular la actividad comercial $y$, por lo tanto, no corresponde al Estado sino que se trata de una actividad ejecutiva propia de las comunidades autónomas que tengan atribuida esta competencia en base a su estatuto de autonomía ${ }^{31}$.

Hasta aquí la exégesis del artículo 93 de la Constitución, sin duda uno de los artículos más trascendentes del Texto Constitucional por las consecuencias que su activación ha significado. Un importante sector de

30 Cfr. Abellán Honrubia, Victoria y VILÀ Costa, Blanca: Lecciones de Derecho..., op. cit., pág. 139. Al tratar las relaciones entre el ordenamiento jurídico comunitario y el ordenamiento español, se plantea muy acertadamente la competencia del Estado o de las Comunidades Autónomas sobre el desarrollo normativo, reglamentario, administrativo y ejecutivo del Derecho comunitario. "Los articulos 148 y 149 de la Constitución española establecen una distribución de competencias entre el Estado, entendido èste en sentido estricto (Administración Central del Estado) y las Comunidades Autónomas, en materias cubiertas claramente por la acción comunitaria, y en consecuencia, el ejercicio de las cuales se ha atribuido a las Instituciones comunitarias. A su vez, los distintos estatutos de autonomía de las Comunidades Autónomas se pronuncian en un doble plano: por una parte, asumen competencias de "relevancia comunitaria" en distintos niveles (legislativas, reglamentarias, administrativas y ejecutivas. $Y$ por otra parte, se pronuncian acerca de su papel y función en materia de ejecución de Tratados internacionales».

31 Sobre la delimitación del titular competente para ejecutar las disposiciones del Derecho comunitario, cfr. también la STC 146/1996, de 19 de septiembre, que resuelve un recurso de insconstitucionalidad interpuesto por el Gobierno vasco contra una ley estatal, limitadora de funciones propias de la Comunidad Autónoma de Euskadi; y la STC 147/1996, de 19 de septiembre, relativa a un conflicto positivo de competencia promovido por el Consejo Ejecutivo de la Generalitat de Cataluña. 
la doctrina científica califica el artículo 93 como un «supuesto de autorruptura constitucional ${ }^{32}$ en atención a las modificaciones que ha implicado en el ámbito normativo. De forma más matizada, se ha escrito que «el artículo 93 es, materialmente, un procedimiento especial de reforma constitucional ${ }^{33}$, a la vista de cómo ha quedado afectada la parte orgánica de la Constitución tras el ingreso de España a la Unión Europea -en el ámbito legislativo, ejecutivo, judicial y autonómico-. Finalmente, entendido como el precepto que abre las puertas de Europa a España y vista la evolución del proceso de unificación europea, se puede concluir que ha favorecido «una mutación constitucional de gran alcance» ${ }^{34}$.

\section{CONFLICTO ENTRE NORMA COMUNITARIA Y CONSTITUCIÓN}

Una vez admitido que los pilares básicos del Derecho comunitario son su aplicación inmediata en los países comunitarios y la primacía de sus normas sobre las disposiciones nacionales, se trata de determinar cómo encajan estos principios en el ordenamiento jurídico español, inspirado en la supremacía y aplicación directa de la Constitución, $y$, más concretamente, si la aplicación del Derecho comunitario se ha de realizar de forma preferente al ordenamiento interno español y si se halla jerárquicamente por encima de la propia Constitución.

En principio, cualquier conflicto entre la norma comunitaria y la Constitución debe ser contemplado desde la perspectiva del artículo 93 de la Constitución ${ }^{35}$, mediante el cual el legislador queda habilitado para limitar la soberanía estatal mediante la transferencia del ejercicio de determinadas competencias a una organización supranacional. A su vez, y dada la especial naturaleza y eficacia del Derecho comunitario, éste se convierte en Derecho propio de cada uno de los Estados miembros, "en la misma medida que el Derecho creado por los órganos constitucionales de cada Estado» ${ }^{36}$. Por tanto, este precepto, por un

32 Cfr. Figueruelo Burkieza, Ángela: "Acotaciones al tema de las relaciones entre el Derecho comunitario y el Derecho internom, en Revista de Estudios Políticos, núm. 51, 1986, págs. 193-195.

33 Cfr. Ruiz Robledo, Agustín: «El ordenamiento juridico...», op. cit., págs. 38-39.

34 Cfr. MuÑoz MACHADO, Santiago: La Unión europea y las mutaciones del Estado, Alianza Universidad, Madrid, 1983, pág. 59.

35 Cfr. Mangas Martin, Araceli: Derecho Comunitario europeo y Derecho español, Tecnos, Madrid, 1987, pág. 142.

36 Cfr. Garcia de Enterría, Eduardo y Fernández, Tomás-Ramón: Curso de Derecho Administrativo I, Civitas, Madrid, 1993, pág. 148. 
lado, "legitima el despliegue de todos los efectos de las normas comunitarias, sean éstas de los Tratados o del Derecho derivado; por otra parte, inserta a nuestro país en el contexto obligacional expresado en el artículo 5 del Tratado de la CEE, y lo somete al principio de fidelidad comunitaria» ${ }^{37}$.

Así las cosas, el Derecho comunitario produce efecto directo y goza de primacía sobre el Derecho de los Estados miembros. Todo ello ha sido posible gracias al artículo 93 , que "ha permitido que se alteren las relaciones internormativas inicialmente previstas por la Constitución ${ }^{38}{ }^{38}$ del mismo modo que el artículo $150 \mathrm{CE}$ ha significado una importante revisión del sistema de fuentes en el ámbito de las comunidades autónomas. Ahora bien, la siguiente cuestión que se puede plantear es la de si ello significa que la Constitución ha dejado de ser la norma suprema del ordenamiento jurídico español.

En principio, la integración en Europa ha significado la aceptación de importantes limitaciones a la soberanía estatal y el reconocimiento de cambios sustanciales en la organización y funcionamiento de la estructura estatal. Sin embargo, ello no ha afectado al elemento básico y originario, al aspecto substancial del sistema constitucional: el poder constituyente ${ }^{39}$. Por tanto, la fuerza y la vinculación de la Constitución se mantienen intactas tras la adhesión de España a las Comunidades Europeas. Aun cuando se ha producido una revisión del sistema de fuentes establecido por el Texto Constitucional, una variación en el marco de actuación del poder ejecutivo, una modificación de la potestad jurisdiccional y una alteración del régimen competencial del Estado y de las Comunidades autónomas, podemos concluir

37 Cfr. Abellán Honrubia, Victoria y VILÀ Costa, Blanca: Lecciones de Derecho..., op. cit., pág. 133. En este mismo sentido, Mangas MARTí, Araceli: Instituciones de Derecho..., op. cit., pág. 205. 144.

38 Cfr. BASTIDA, Francisco J. y otros: Derecho Constitucional..., op. cit., pág.

39 No obstante, Santiago Muñoz Machado (La Unión europea..., op. cit., págs. 59-60) entiende que, si la mutación constitucional experimentada tras al proceso de integración europea "se produce por impulsos políticos y jurídicos externos a las instituciones estatales y sin seguir los procedimientos establecidos para la reforma de la Constitución, me parece que puede sentarse esta tesis final: la integración europea está produciendo una traslación del poder constituyente hacia instancias supranacionales. Las decisiones fundamentales comunitarias alteran el contenido de la Constitución y se imponen a la misma, van cambiando sus características, no sólo por causa de la aprobación de Tratados que transfieren a la Comunidad Europea competencias derivadas de la Constitución, sino por el modo cómo se ejercen esas competencias ulteriormente". 
que la Constitución no ha dejado de ser la norma suprema del ordenamiento jurídico. No obstante, se pueden examinar las relaciones entre el Derecho interno, el Derecho comunitario y la Constitución desde un triple punto de vista: las conexiones entre el Derecho comunitario y la ley interna, la colisión entre los Tratados constitutivos y la Constitución, y el conflicto entre Derecho derivado y la Norma Fundamental, especialmente en relación a los derechos fundamentales y las libertades públicas.

\section{A) Relación entre la ley interna y el Derecho comunitario}

El hecho de que la norma comunitaria (de los Tratados o del Derecho derivado) sea obligatoria con eficacia inmediata y prevalezca sobre el Derecho español, supone que, en todas aquellas materias cuyo ejercicio se haya atribuido a las Comunidades Europeas, se producirá una sustitución de las disposiciones nacionales por las de los Tratados comunitarios y las de Derecho derivado. Por tanto, la relación entre el Derecho interno y el Derecho comunitario no se mide a través de la superioridad jerárquica de este último, sino que puede equipararse a la relación existente entre dos normas jurídicas del mismo rango, relación que está presidida por el principio de competencia ${ }^{40}$. Así, el Derecho comunitario deberá controlar todas aquellas materias sobre las que haya asumido competencias, sin que intervenga el Derecho interno más que en aquellos casos en que sea preciso, para que los actos de las Instituciones comunitarias tengan plena eficacia ${ }^{41}$.

El eventual conflicto entre normas internas y normas comunitarias, en principio, no tendría que provocar ningún problema, dado que la aplicación efectiva de estas últimas sobre las disposiciones internas viene garantizada por los principios de eficacia directa y primacía del Derecho comunitario. Sin embargo, quizá por tradición o simple iner-

Cfr. Ruiz RoBledo, Agustín: «El ordenamiento jurídico...», op. cit., pág. 50.

41 El principal problema que se plantea en este punto es, tal como señala Isidre Molas Batllori (Derecho..., op. cit., pág. 275), el "déficit democrático" de los órganos de gobierno europeos y la inexistencia de un auténtico poder legislativo en manos del Parlamento. Ello determina que la superposición del sistema normativo comunitario contrasta con el tradicional sistema democrático de fuentes del Derecho. Precisamente, ese déficit democrático es el que justifica, en opinión del Tribunal Constitucional alemán, la prevalencia de la Constitución en caso de conflicto entre el Derecho comunitario y la Constitución, cuestión que se mantendrá en tanto no se solvente esta deficiencia (STC alemán de 29 de mayo de 1974). 
cia, se ha observado una actitud reticente por parte de los jueces nacionales ante la prevalencia de la norma comunitaria sobre el Derecho de los Estados miembros, cualquiera que sea su rango. Este principio ha dado lugar a un exhaustivo debate sobre la aplicación del Derecho comunitario tanto por parte de la jurisprudencia como de la doctrina científica ${ }^{42}$.

Existe, además, otro problema. En un sistema de distribución de funciones entre los distintos poderes estatales en base al principio de la separación de poderes, se constata una vinculación de cada uno de los poderes a sus concretas atribuciones. En principio, y por lo que a nosotros nos interesa, el juez administra justicia sometido al imperio de la ley (art. $117 \mathrm{CE}$ ). Lo cual significa que el juzgador debe valerse de las leyes para emitir la resolución judicial correspondiente y que no puede dejar de aplicarlas. La única opción del juez para inaplicar una ley es plantear la cuestión de inconstitucionalidad ante el Tribunal Constitucional, en la forma y con los efectos que establezca la ley, "cuando un órgano judicial considere, en algún proceso, que una norma con rango de ley, aplicable al caso, de cuya validez dependa el fallo, pueda ser contraria a la Constitución" (art. $163 \mathrm{CE}$ ). A la vista de lo cual, la única posibilidad de que el juez deje de aplicar una ley es que ésta sea declarada inconstitucional. En cambio, según la jurisprudencia del Tribunal de Justicia de las Comunidades Europeas en la Sentencia del caso Simmenthal, el juez nacional encargado de aplicar, en el marco de su competencia, las disposiciones del Derecho comunitario, tiene la obligación de asegurar el pleno efecto de estas normas, dejando inaplicada si fuese necesario, en virtud de su propia autoridad, toda disposición contraria, incluso posterior. El problema que, en definitiva, se plantea es uel de la relevancia constitucional de los eventuales conflictos que puedan suscitarse entre las normas comunitarias y las normas internas con rango de ley posteriores a aquéllas, pues únicamente en el caso de que aquél reconociera dicha relevancia podría estimarse competente para entrar a determinar si, efectivamente, se daba esa contradicción ${ }^{43}$. Se trata de determinar, por tanto, si el con-

42 Especialmente intenso ha sido el debate, sobre todo a nivel jurisprudencial, en Francia, dada la divergente opinión que mantenían el Consejo de Estado y la Corte de Casación, sobre la primacía de la norma interna. Este debate jurisprudencial ha sido recogido por Santiago MUÑOZ MACHADO: La Unión europea..., op. cit., págs. 70-73.

43 Cfr. Sánchez Legido, Ángel: «Las relaciones entre el Derecho comunitario y el Derecho interno en la Jurisprudencia del Tribunal Constitucional» en Revista Española de Derecho Constitucional, núm. 33, 1991, pág. 177. 
flicto entre el Derecho comunitario y el Derecho interno debe medirse según los parámetros de la constitucionalidad o si queda excluido del control de constitucionalidad.

En un primer momento, los Tribunales Constitucionales alemán e italiano plantearon una serie de reservas al principio de la primacia y efecto directo del Derecho comunitario en el ámbito de los derechos fundamentales. Propugnaban que fueran sus propias jurisdicciones las que resolvieran los eventuales conflictos que pudieran plantearse, $y$ defendían que debian ser sus propias Constituciones las que amparasen las disposiciones sobre derechos y principios fundamentales, incluso en el marco de las Comunidades Europeas ${ }^{44}$. Por un lado, el Tribunal Constitucional alemán, en la Sentencia de 29 de mayo de 1974, señala que, en caso de conflicto entre Derecho comunitario y los derechos fundamentales garantizados en la Ley Fundamental, deberá prevalecer la Constitución, "en tanto la Comunidad no se dote de un Parlamento democráticamente elegido y con atribuciones legislativas $y$ ante el que los órganos comunitarios serían responsables políticamente, y de un catálogo codificado de derechos fundamentales semejantes al de la Ley Fundamental» ${ }^{45}$.

En similares términos -o incluso más duros- se resuelve en Italia la confrontación entre el Derecho comunitario y una norma posterior con rango de ley, pues en su primera doctrina (Sentencia de 23 de diciembre de 1973) el Tribunal Constitucional italiano reconduce aquel problema a un proceso sobre la constitucionalidad de la ley interna y exige a los jueces nacionales plantear la cuestión de inconstitucionalidad sobre la misma ${ }^{46}$. No obstante, el Tribunal Constitucional italiano, en la Sentencia de 1 de febrero de 1975, actuó con mayor mesura ante este difícil problema. Así, partiendo de la idea de que las disposiciones de los Tratados ofrecen una garantía segura para la protección de los derechos fundamentales, el Alto Tribunal ejercería un control sobre la "compatibilidad constante de los Tratados con los principios fundamentales del orden jurídico constitucional, y los derechos inalienables de la persona humana sólo en el caso, más que límite, casi impensable, de que las Instituciones hiciesen un uso o una interpretación abe-

44 No obstante, Santiago Muñoz MACHADO (La Unión europea..., op. cit., pág. 69) cita algunas sentencias de tribunales nacionales como ejemplo del considerable esfuerzo para aceptar el principio de preferencia del Derecho comunitario, aunque éste carecia del suficiente arraigo en el ámbito judicial de los Estados miembros.

45 Cfr. Mangas Martin, Araceli: Derecho Comunitario..., op. cit., pág. 149.

46 Cfr. MuÑoz Machado, Santiago: La Unión europea..., op. cit., pág. 70. 
rrante de sus poderes» ${ }^{47}$. Finalmente, en la Sentencia Granital de 8 de junio de 1984, el Tribunal Constitucional italiano da un giro a su doctrina y se adhiere a la jurisprudencia del Tribunal de Luxemburgo, con lo cual acepta que una norma interna contraria a una norma comunitaria debe ser inaplicada sin necesidad de seguir, con carácter previo, ningún procedimiento de inconstitucionalidad ${ }^{48}$.

En nuestro pais, esta cuestión ha sido resuelta por la jurisprudencia, primero del Tribunal Supremo y más tarde del Tribunal Constitucional, haciendo suyos los criterios del Tribunal de Luxemburgo. En este sentido, la Sentencia del Tribunal Supremo de 24 de abril de 1990 señala que:

"Los reglamentos y las directivas comunitarios tienen valor de leyes marco cuya primacía sobre las normas internas y efecto directo en su caso no podrán ser discutidos, desde el momento de la adhesión a los Tratados fundacionales. Las normas anteriores que se opongan al Derecho comunitario deberán entenderse derogadas y las posteriores contrarias habrán de reputarse inconstitucionales por incompetencia -artículos 93 y 96.1 de la Constitución Española-pero no será exigible que el juez ordinario plantee la cuestión de inconstitucionalidad, porque está vinculado por la jurisprudencia del Tribunal de Justicia que tiene establecido el principio pro comunitate».

Aun cuando no compartimos totalmente la terminología utiliza$\mathrm{da}^{49}$, entendemos que el planteamiento del Tribunal Supremo es correcto, dado que se observa una actitud conciliadora con la doctrina del

47 Cfr. Mangas Martin, Araceli: Derecho comunitario..., op. cit., pág. 152. Para un análisis más detallado de la doctrina constitucional italiana y alemana, véanse, entre otros, a Ángel SÁNCHEZ LEGIDO ( Las relaciones...", op. cit., págs. 177-178) y a Ricardo ALonso GaRCiA ("Derechos fundamentales y Comunidades Europeas" en Estudios sobre la Constitución española. Homenaje al profesor E. García de Enterria, Civitas, madrid, 1991, vol. II, págs. 804-807).

48 Cfr. Muñoz Machado, Santiago: La Unión europea..., op. cit., pág. 70.

49 Dice el Tribunal Supremo que las leyes nacionales posteriores contrarias al Derecho comunitario se consideran "inconstitucionales por incompetencia», cuando entendemos que sería más correcto hablar de "inaplicación" de la norma posterior, pues sólo el Tribunal Constitucional puede declarar la inconstitucionalidad de una ley. Como señala certeramente Araceli MANGAS MARTin (en «Las relaciones entre el Derecho comunitario y el Derecho interno de los Estados miembros a la luz de la jurisprudencia del Tribunal de Justicia», en El Derecho comunitario europeo y su aplicación judicial, pág. 91), «en la antinomia norma comunitaria-norma interna no se le plantea al juez o al órgano administrativo que se pronuncie sobre la validez de la norma interna, sino sobre su aplicabilidad a esa situación». 
Tribunal de las Comunidades Europeas. Por su parte, el Tribunal Constitucional también ha reconocido plenamente los elementos estructurales del Derecho comunitario que garantizan su eficacia directa y su primacia sobre el Derecho interno. La Sentencia 130/1995, de 11 de septiembre ${ }^{50}$, señala que:

«...ha de tenerse en cuenta que España es Estado miembro de las Comunidades Europeas desde el 1 de enero de 1986, de conformidad con las previsiones del art. $93 \mathrm{CE} \mathrm{y,} \mathrm{por} \mathrm{tanto,} \mathrm{sujeto} \mathrm{a} \mathrm{las} \mathrm{nor-}$ mas del ordenamiento comunitario que poseen efecto directo para los ciudadanos y tienen primacía sobre las disposiciones internas, como asi se ha declarado por el Tribunal de Justicia de las Comunidades Europeas...".

A la vista de las resoluciones jurisprudenciales citadas, podemos concluir que se ha producido un cambio de orientación en el plano judicial interno, indispensable para la consecución de los objetivos comunitarios. Hasta el momento, en los Estados miembros los principios de eficacia directa y primacía del Derecho comunitario no desplegaban todos sus efecto, bien por simple ignorancia o desconocimiento del ordenamiento comunitario, bien por la hostilidad de los jueces nacionales a aplicar un Derecho que no le es "propio». Ahora la aplicación del sistema normativo de la Unión Europea se encuentra garantizado por las más altas instancias judiciales de los Estados miembros.

\section{B) Oposición entre Tratados originarios y Constitución Española}

Un segundo nivel de confrontación es el hipotético conflicto entre la Constitución y las disposiciones de los Tratados constitutivos. Se trata de determinar si los documentos fundacionales se ajustan a los textos constitucionales de los Estados miembros y, en caso contrario, cual es la solución a tal conflicto. Esta cuestión ha sido objeto de debate especialmente fecundo en los momentos previos a la ratificación del Tratado de la Unión ${ }^{51}$, dado que en la mayoría de Estados comunitarios se planteó la conveniencia de reformar su Constitución para

50 Fundamento jurídico $4 .^{\circ}$.

51 Santiago Muñoz MACHAdo (La Unión europea..., op. cit., págs. 24 a 31) realiza un excelente trabajo analizando las diferentes posiciones de los Estados miembros sobre la necesidad de modificar la Constitución para adaptarla a los acuerdos de Maastricht. 
evitar incoherencias entre ésta y el Tratado de Maastricht. Según el profesor Muñoz Machado, se han adoptado tres posturas distintas sobre la eventual reforma constitucional. Un primer grupo de países, entre los que se encontraban Bélgica, los Países Bajos y Gran Bretaña -este último por razones obvias-, entendían viable la ratificación del Tratado de Maastricht sin necesidad de adaptar la Constitución, ya que en ellos rige un antiguo principio según el cual los tratados internacionales prevalecen sobre el ordenamiento interno. En un segundo nivel, sitúa aquellos Estados que han optado por la reforma constitucional reducida a la mínima expresión, circunstancia que se ha producido, por ejemplo, en Luxemburgo y en España. Finalmente, el tercer modelo, seguido por Portugal, la República Federal Alemana y Francia, estaría formado por aquellos países que han entendido que la ratificación del Tratado de la Unión requería, con carácter previo y necesario, la inclusión en el texto constitucional de una cláusula que amortigüe el impacto que aquella actuación provocará en sus sistemas nacionales. Se observa, por tanto, un esfuerzo por parte de los distintos países miembros de las Comunidades para adaptar su Constitución al Tratado de Maastricht, bien sea a través de reformas lacónicas o bien sea a través de una amplia modificación constitucional.

El constituyente español, para evitar contradicciones entre sus mandatos y los acuerdos internacionales, legitimó al Tribunal Constitucional para investigar aquella circunstancia y, si en su examen llegaba a la conclusión de que existía efectivamente tal contradicción, la Constitución debería ser reformada antes de que se ratifique el Tratado en cuestión ${ }^{52}$. El único inconveniente que presenta este mecanismo de control es que no se exige con carácter preceptivo, sino que queda a la libre apreciación del Gobierno o de cualquier de las Cámaras legislativas plantear este recurso ante el Alto Tribunal. Sea como fuere, el proceso en cuestión, denominado control previo de constitucionalidad de

52 El fundamento normativo que permite seguir este proceso es el artículo 95 de la Constitución, según el cual «la celebración de un tratado internacional que contenga estipulaciones contrarias a la Constitución exigirá la previa revisión constitucional. El Gobierno o cualquiera de las Cámaras puede requerir al Tribunal Constitucional para que declare si existe o no esa contradicción». $Y$, de acuerdo con el artículo 78 de la Ley Orgánica del Tribunal Constitucional, el Gobierno o cualquiera de ambas Cámaras podrán requerir al Tribunal Constitucional para que se pronuncie sobre la existencia de contradicción entre la Constitución y las estipulaciones de un tratado internacional cuyo texto estuviera ya definitivamente fijado, pero al que no se hubiese prestado aún el consentimiento del Estado. En estos casos, el Tribunal Constitucional emitirá una declaración que tendrá carácter vinculante. 
los tratados internacionales, permite al Tribunal Constitucional determinar "si la atribución de competencias que exigen los Tratados va más allá de lo contemplado en el artículo 93 de la Constitución, hasta el punto de que tal desposeimiento del ejercicio de competencias ponga en peligro la existencia misma de la Constitución que permitió la cesión ${ }^{53}$. Con esta base jurídica, el Gobierno español requirió al Tribunal Constitucional para que declarara si el Tratado de la Unión Europea firmado en la ciudad de Maastricht vulneraba algún aspecto de la Constitución; la declaración del Tribunal Constitucional de 1 de julio de 1992 fue que el artículo 8B del Tratado constitutivo de la CEE (añadido por el artículo $\mathrm{G}$ del Tratado de la Unión Europea ${ }^{54}$ era contrario al artículo 13.2 de la Constitución -que solamente reconocía el derecho de sufragio activo a los extranjeros en las elecciones municipales-, con lo cual era necesaria su reforma por la vía del artículo 167 para que dicho Tratado pudiera ser ratificado. Por lo tanto, se optó por revisar mínimamente aquellos aspectos que colisionaran directamente con alguna de las disposiciones del Tratado de la Unión.

La decisión de adoptar una reforma parcial y limitadísima de la Constitución, totalmente legítima a la vista de la resolución del Tribunal Constitucional, tiene la ventaja de que la firma del Tratado de la Unión se produce con las mínimas "molestias" por lo que a mecanismos de adaptación se refiere. Pero, en nuestra opinión, resulta insuficiente al no reflejar los cambios mucho más profundos y el impacto social que supondrá la ratificación de aquel acuerdo comunitario. Mucho más correcta nos parece la actuación del constituyente portugués que, ante la encrucijada de la conclusión de un acuerdo destinado a la creación de una ciudadanía comunitaria, aprovechó la Ley de Reforma Constitucional 1/1992, de 25 de noviembre, para ampliar la capacidad electoral de los extranjeros residentes en el territorio nacional para las elecciones a los órganos de las corporaciones locales (art. 15.4) y añadir una cláusula más amplia que permita la consecución de los intereses comunitarios en el precepto relativo a las relaciones internaciona-

53 Cfr. Mangas Martín, Araceli: Derecho comunitario..., op. cit., pág. 142.

54 Según éste el apartado 1 de este precepto, «todo ciudadano de la Unión que reside en un Estado miembro del que no sea nacional tendrá derecho a ser elector y elegible en las elecciones municipales del Estado miembro en el que resida, en las mismas condiciones que los nacionales de dicho Estado. Este derecho se ejercerá sin perjuicio de las modalidades que el Consejo deberá adoptar antes del 31 de diciembre de 1994, por unanimidad, a propuesta de la Comisión y previa consulta del Parlamento Europeo; dichas modalidades podrán establecer excepciones cuando asi lo justifiquen problemas específicos de un Estado miembro". 
Por consiguiente, nos encontramos ante una de las cuestiones más conflictivas que han surgido en el ámbito de la Comunidad Europea, concretamente la de "si las consentidas transferencias de soberanía en favor de las Instituciones comunitarias, que resultan de la firma de los Tratados, pueden hacer admisible que las resoluciones que se adopten en desarrollo de los mismos resulten aplicables aunque supongan, por su contenido, una rebaja en el estándar de derechos individuales consagrados en la Constitución o un atentado a alguno de ellos en concreto" ${ }^{61}$. Si, tal como resulta de la particular naturaleza del Derecho comunitario, se proclama la «primacia de todas sus normas (originarias y derivadas) respecto a cualquier norma interna, incluso constitucional ${ }^{62}$, cabría la posibilidad de que la protección dispensada por el Derecho comunitario a los derechos fundamentales fuera menor a la que reciben en el ordenamiento interno de algún Estado miembro.

La preocupación de los Estados miembros en este ámbito se constata en los pronunciamientos jurisprudenciales de los Tribunales Constitucionales italiano y alemán. Sin embargo, la injerencia de las jurisdicciones nacionales plantea un nuevo interrogante: ¿son realmente competentes los Tribunales internos para solventar un litigio afectado por la aplicación de disposición comunitaria contraria a una disposición interna -aunque tenga rango constitucional-? Si partimos de la premisa de que las normas de Derecho derivado integran un sistema jurídico nuevo y diferente del ordenamiento interno ${ }^{63}$, debemos aceptar que ula singularidad del ordenamiento comunitario no concluye en la creación de un sistema normativo propio, capaz de imponerse a las disposiciones internas de cada Estado miembro, sino que presenta, además, otra característica...; se trata de que cuenta con un sistema jurisdiccional propio que es el único ante el que se pueden residenciar las cuestiones contenciosas que puedan suscitar las normas comunitarias ${ }^{64}$. Por tanto, siendo el único juez de la legalidad comunitaria el Tri-

61 Cfr. Muñoz MaChado, Santiago: El ordenamiento jurídico..., op. cit., pág. 37. En esta misma línea, el profesor Pablo Pérez Tremps (Constitución española y Comunidad Europea, Civitas, 1994, pág. 161) señala la posibilidad de que a través de las Comunidades Europeas se pueda rebajar el nivel de protección que internamente tienen garantizados los derechos fundamentales.

62 Cfr. Mangas Martin, Araceli: Instituciones de Derecho..., op. cit., pág. 205.

63 Cfr. Mangas Martin, Araceli: Derecho comunitario..., op. cit., pág. 144.

64 Cfr. Muñoz Machado, Santiago: El ordenamiento juridico..., op. cit., pág. 67. En esta misma línea, Ángela Figueruelo Burrieza ( "Derecho comunitario...", op. cit., pág. 202) señala que «entre la transferencia de competencias que el artículo 93 de la CE permite se encuentran también las de tipo jurisdiccional. Dado el régimen 
bunal de Justicia de la Comunidad (arts. 164 y 188 del Tratado de la CEE), el control de las normas de Derecho derivado no puede corresponder al Tribunal Constitucional nacional, sino que se exige aceptar un sistema de protección jurisdiccional propio del orden comunitario.

Los Tratados impiden que el juez nacional pueda juzgar la validez de la norma de Derecho derivado, lo cual no significa que deba abstenerse de cualquier intervención en aras a favorecer y mejorar la aplicación del ordenamiento comunitario en los Estados miembros. Se les reconoce, en efecto, una participación activa a los jueces nacionales para resolver los eventuales conflictos entre las disposiciones nacionales y las de Derecho derivado, dado que la relación entre el orden interno y el orden comunitario no es tan rígida que suponga su exclusión. En particular, se les encomienda el planteamiento de una cuestión prejudicial (artículo 177 del Tratado de la CEE, artículo 150 del Tratado de la CEEA y artículo 41 del Tratado de la CECA) ${ }^{65}$. A través de este recurso, reconocido como vemos en los tres Tratados Constitutivos, el juez nacional que duda de la validez o del contenido y alcance de los actos del Derecho derivado puede acudir al Tribunal de Justicia de la Comunidad para que se pronuncie sobre su validez e interpretación o cuando "los tribunales internos pretendan apartarse de la jurisprudencia del Tribunal de Justician ${ }^{66}$. Incluso se reconoce a los particulares la posibilidad de «impugnar directamente la legalidad de los actos del Consejo o de la Comisión, ya sea la infracción por incompetencia, violación de formas sustanciales, violación del Tratado o toda regla de derecho relativa a su aplicación o por desviación de poder (arts. 173 y 184 Tratado CEE) ${ }^{67}$.

Asi las cosas, queda claro, por un lado, que no existe una auténtica declaración de derechos en el ámbito comunitario, con la consiguiente preocupación de que tal ausencia suponga vulneración u ofensa a los derechos constitucionales nacionales. Por otra parte, se constata la incompetencia de los Tribunales Constitucionales para solventar estas cuestiones, pues ante un conflicto entre una disposición

de exclusividad en que el orden jurisdiccional de la Comunidad se organiza, las jurisdicciones nacionales carecen de competencia para enjuiciar normas o resoluciones comunitarias, ya que esta operación queda reservada al Tribunal de Luxemburgo, único órgano que conoce de tales cuestiones». 68-69.

65 Cfr. Muñoz MACHADO, Santiago: El ordenamiento jurídico..., op. cit., págs.

66 Cfr. Muñoz Machado, Santiago: La Unión europea..., op. cit., pág. 77.

67 Cfr. Mangas Martín, Araceli: Derecho comunitario..., op. cit., pág. 146. 
cia del Derecho comunitario, tendría por efecto, irremisiblemente, quebrar la unidad del mercado común y poner en peligro la cohesión de la Comunidad" ${ }^{74}$.

No obstante lo anterior, se observa un esfuerzo por parte de la doctrina del Tribunal comunitario para flexibilizar su postura, en aras a la consecución de cierta armonización en el tratamiento de los derechos fundamentales y libertades públicas, buscando puntos de contacto, elementos compartidos, para lograr la seguridad jurídica $y$, muy especialmente, para garantizar los intereses de los ciudadanos a nivel comunitario. Lo cual no significa que se deba examinar la conformidad de la norma comunitaria con el contenido de los derechos fundamentales proclamados en una concreta constitución, sino que cabe buscar una serie de elementos cualitativos comunes de los ordenamientos internos en materia de derechos fundamentales, los cuales han de ser aplicados en el ámbito comunitario ${ }^{75}$.

Sea como fuere, observamos una importante preocupación por parte del Tribunal de Justicia de velar por la protección de los derechos fundamentales en el ámbito comunitario, tanto si las agresiones frente a los mismos provienen de las Instituciones comunitarias como si proceden de las actuaciones de los Estados miembros ${ }^{76}$. Además, hay que reconocer que cada vez deberían plantearse menos colisiones entre el ordenamiento nacional y el ordenamiento comunitario en el campo de los derechos fundamentales, pues "por una parte, las técnicas hermenéuticas de la integración tienden... a hacer realidad una unificación en la protección de derechos fundamentales en una especie de ius commune: el precedente de los principios constitucionales que comparten los Estados miembros y del Convenio Europeo de Derechos Humanos, tal y como ahora dispone el artículo $\mathrm{F}$ del Tratado de la Unión Europea; por otra parte, también desde la perspectiva estatal, la unificación de los ordenamientos nacionales es cada vez mayor, no sólo por sus mutuas influencias, sino por la creciente importancia de los instrumentos internacionales de protección de derechos fundamentales, en especial del Convenio Europeo de Derechos Humanos y de la labor interpretativa del Tribunal

74 Sentencia del Tribunal de Justicia de 13 de diciembre de 1979, asunto 44/79, Hauer, Rec. 1979, pág. 3744.

75 Cfr. Mangas Martin, Araceli: Derecho comunitario..., op. cit., pág. 157.

76 Para un análisis más exhaustivo de la jurisprudencia del Tribunal de Justicia de las Comunidades Europeas en materia de derechos fundamentales -en particular sobre la inviolabilidad del domicilio-, puede consultarse nuestro trabajo La intimidad como fundamento..., op. cit., págs. 113-120. 
Europeo de Derechos Humanos $)^{77}$. No obstante, entendemos que sería preferible, en aras a la seguridad jurídica, establecer en un documento internacional a nivel comunitario, una relación generosa y abierta de derechos y libertades públicas, con un adecuado mecanismo de garantías (sean de tipo estructural, de procedimiento, de control y, especialmente de tipo jurisdiccional) ${ }^{78}$; lo cual supone plantear la conveniencia de iniciar un proceso constituyente en el ámbito comunitario, cuestión que no nos corresponde analizar ni por el tiempo ni por el lugar.

\section{JURISPRUDENCIA DEL TRIBUNAL CONSTITUCIONAL ESPAÑOL}

El Tribunal Constitucional español también ha tenido ocasión de resolver las relaciones entre la Constitución y el ordenamiento jurídico comunitario. Los recursos interpuestos ante el Tribunal Constitucional traen causa de una hipotética vulneración de derechos constitucionales a la vista de la eventual confrontación entre normas de Derecho nacional y disposiciones comunitarias. En las resoluciones que vamos a comentar a continuación observamos el talante moderador del Alto Tribunal, pues pretende conciliar la supremacía del poder estatal -la soberanía nacional, en definitiva, y el respeto a la Constitución- acatando los límites inherentes a la adhesión a una comunidad supranacional, a través del respeto a las normas que se acuerden en este ámbito. Esto último permite al Tribunal declararse incompetente para resolver tales conflictos y remitir a la jurisdicción ordinaria tal atribución en cumplimiento de sus funciones.

\section{A) Sentencia del Tribunal Constitucional 28/1991, de 14 de febrero}

Dicha Sentencia resuelve un recurso de inconstitucionalidad planteado por el Parlamento vasco contra algunos preceptos de la Ley de reforma de la LO 5/1985, de 19 de junio, del Régimen Electoral General (LOREG), en relación a las elecciones al Parlamento Europeo. El asunto que más nos interesa es la impugnación del artículo 211.2.d) de la LOREG, el cual establece la incompatibilidad entre el cargo de diputado autonómico y diputado europeo $y$, por consiguiente, supone la infrac-

77 Cfr. Pérez Tremps, Pablo: Constitución española..., op. cit., pág. 163.

78 Cfr. Oliver Araujo, Joan: El recurso de amparo, Facultad de Derecho de Palma de Mallorca, Palma, 1986, págs. 25-27. 
órganos judiciales en los litigios de que conozcan ${ }^{83}$. En definitiva, configura el hipotético conflicto entre una norma interna y el Derecho comunitario como un «conflicto de normas infraconstitucionales que ha de resolverse en el ámbito de la jurisdicción ordinarian.

Un sector de la doctrina ha criticado la "ambigüedad" ${ }^{84}$ o "gratuidad ${ }^{85}$ del Tribunal Constitucional al referirse a la colisión entre una norma comunitaria y una disposición interna como un conflicto de normas «infraconstitucionales». Si esta terminología se interpreta en sentido literal hay que reconocer la contradicción entre la jurisprudencia constitucional española y la jurisprudencia del Tribunal de Luxemburgo, pues ésta ha consagrado el principio de la inoponibilidad frente a las normas comunitarias de normas internas, incluso en el supuesto de que se tratara de mandatos constitucionales. Efectivamente, recordemos que al interpretar el artículo 96.1 el Tribunal no reconoce expresamente la primacía de los tratados internacionales frente a la ley; además, parece que el Alto Tribunal ha venido a reconocer implícitamente que en el caso de que se plantease un eventual conflicto entre la Constitución y unanorma comunitaria debería prevalecer la primera ${ }^{86}$.

¿A quién corresponde, por tanto, la resolución del conflicto planteado? ¿Cuál es el derecho aplicable al caso? Reconocido el carácter autónomo y particular del Derecho comunitario y admitida la sujeción del Estado español a las obligaciones inherentes a la adhesión comunitaria, el Tribunal señala que "serán entonces los órganos judiciales quienes, en los procesos correspondientes, hayan de pronunciarse sobre la repetida contradicción..., a cuyo fin dichos órganos están facultados (u obligados según los casos) para pedir al Tribunal de Justicia de la Comunidad Europea, de conformidad con lo dispuesto en el artículo 177

83 STC 28/1991, de 14 de febrero, fundamento jurídico $5 .^{\circ}$.

84 Cfr. SÁNCHEZ LegIDo, Ángel: "Las relaciones...", op. cit., pág. 184.

85 Cfr. Mangas Martin, Araceli: Instituciones de Derecho..., op. cit., pág. 205). Esta autora recuerda que la doctrina del Tribunal de Justicia es en este punto inamovible: la supremacía del Derecho comunitario es absoluta sobre cualquier norma de un Estado miembro, incluso constitucional.

${ }_{86}$ Este argumento también es manejado por Santiago Muñoz Machado ( $E I$ ordenamiento jurídico..., op. cit., págs. 92-93), al admitir que, cuando una norma comunitaria rebaja el nivel de protección de los derechos reconocidos en la Constitución o los desconoce, este conflicto deberá reservarse al Tribunal Constitucional. Es una manifestación más de la inercia provocada por las primeras resoluciones de los Tribunales Constitucionales nacionales reticentes ante la inexistencia de mecanismos adecuados de defensa y garantía de los derechos y libertades en el ámbito comunitario. 
del Tratado de la CEE y preceptos concordantes de los demás tratados constitutivos, una declaración interpretativa..." sobre el alcance de la norma comunitaria. Para completar este razonamiento admite que, «tratándose de verificar únicamente la acomodación de una norma nacional a otra del Derecho comunitario europeo, la primacía de éste exige que sean sólo aquellos órganos (judiciales, aunque debemos ampliar esta expresión a todos los poderes del Estado) los llamados a asegurar directamente la efectividad de tal Derecho ${ }^{87}$.

Finalmente, el Alto Tribunal niega, con buen criterio, la posibilidad de que sea el propio Tribunal Constitucional el encargado para dirigirse al Tribunal de Justicia en vía prejudicial -en virtud de la previsión establecida en el art. 177 del Tratado de la CEE-, para que éste determine «si del artículo 5 del Acta Electoral Europea debe derivarse la compatibilidad entre la condición de miembro del Parlamento y la pertenencia al Parlamento Vascon. Como afirma el Abogado del Estado en sus alegaciones, "el Derecho comunitario europeo tiene sus propios órganos de garantía, entre los cuales no se encuentra este Tribunal». $Y$ el Tribunal Constitucional reitera que la acomodación entre una norma de Derecho derivado y una ley nacional "no es un problema constitucional ${ }^{88}$. Por tanto, el Tribunal, se limita a negar el reenvío en el caso conçreto que está conociendo, pero no resuelve el problema de si tiene capacidad para plantear, en general, cuestiones prejudiciales.

El reenvío prejudicial (art. 177 Tratado CEE, art. 41 Tratado CECA y art. 150 Tratado Euratom) es un "mecanismo de articulación entre justicia comunitaria e interna», cuya función esencial consiste en "asegurar la aplicación uniforme del Derecho comunitario" 89 . En relación a la legitimación para interponer la cuestión prejudicial, la normativa comunitaria distingue entre aquellas jurisdicciones nacionales con «derecho a recurrir» de aquellas que cuentan «con obligación de recurrir». En el primer

87 STC 28/1991, 14 de febrero, fundamento jurídico $6 .^{\circ}$. A continuación recuerda la doctrina fijada por el Tribunal de Justicia en el caso Simmenthal, según la cual no serían de recibo normas nacionales que pudieran perturbar la plena eficacia de las disposiciones comunitarias, estimando que «ése sería el caso si, en la hipótesis de contradicción entre una disposición del Derecho comunitario y una ley nacional posterior, la solución a este conflicto fuera reservada a una autoridad distinta del juez llamado a asegurar la aplicación del Derecho comunitario, investida de un poder de apreciación propio, incluso si el obstáculo que así resulta no fuera más que temporal».

${ }_{88}$ STC 28/1991, de 14 de febrero, fundamento jurídico $7:^{\circ}$.

89 Cfr. Abellán HonRubia, Victoria y Vilà Costa, Blanca: Lecciones de Derecho..., op. cit., pág. 166. 
tiza que la vulneración de un derecho fundamental por parte de un acto del poder público (aunque sea adoptado para la ejecución de una disposición comunitaria) entra en el ámbito de la Corte Constitucional, admitiendo previamente que, tanto en el ámbito interno como a nivel comunitario, existe una protección equiparable y adecuada contra los actos discriminatorios respecto de los ciudadanos comunitarios. Finaliza su razonamiento señalando que "en el presente asunto a este Tribunal no le corresponde resolver si la actividad de los poderes públicos aquí impugnada se acomoda o no al Derecho comunitario europeo. El único problema sobre el que hemos de pronunciarnos es el de si la normativa estatal y los actos de ejecución aplicados a los recurrentes se compadecen o no con las exigencias de igualdad y no discriminación del art. $14 \mathrm{CE})^{97}$.

Avanzando un paso más en las relaciones entre el Derecho interno y el Derecho comunitario, interpreta el Alto Tribunal que «la cesión del ejercicio de competencia en favor de organismos supranacionales no implica que las autoridades nacionales dejen de estar sometidas al ordenamiento interno cuando actúan cumpliendo obligaciones adquiridas frente a tales organismos, pues también en estos casos siguen siendo poder público que está sujeto a la Constitución y al resto del ordenamiento jurídico español (art. 9.1) $1{ }^{98}$. Dicho con otras palabras, de la doctrina del Tribunal Constitucional se desprende el sometimiento de los actos de las autoridades españolas que ejecutan normas comunitarias al Derecho comunitario y al Derecho interno español, cuando aquéllos sean susceptibles de vulnerar un derecho constitucional. No obstante, el enjuiciamiento de sus actuaciones corresponde al Tribunal de Justicia a través del recurso interpuesto a instancia de la jurisdicción ordinaria nacional99.

97 STC 64/1991, de 22 de marzo, fundamento jurídico $4 .^{\circ}$-a).

98 lbidem, fundamento jurídico $4 .^{\circ}-b$ ). Desautoriza, por tanto, el Tribunal Constitucional la opinión mantenida por el Abogado del Estado, el cual, en una lectura pro comunitate, entiende que "la autoridad administrativa española ha actuado en el presente caso no como un poder público estatal, sino como órgano del ordenamiento comunitario en cuanto ha dictado un acto preparatorio" (STC 64/1991, de 22 de marzo, antecedentes 15-c).

99 Tal como afirma Ángel SÁNCHEZ LEGIDO (en "Relaciones entre derecho...", op. cit., pág. 196), "la función de controlar el respeto del Derecho comunitario por los poderes públicos españoles corresponderá, en consecuencia, ya se trate de actos del legislativo o del ejecutivo, a los órganos de la jurisdicción ordinaria, a cuyos efectos podrán o deberán, según los casos, plantear la correspondiente cuestión prejudicial ante el Tribunal de Luxemburgo». 


\section{C) Sentencia del Tribunal Constitucional 180/1993, de 31 de mayo}

Esta Sentencia trata la cuestión de la aplicación directa de una Directiva de la CEE. Concretamente, los recurrentes entienden vulnerado el derecho a la tutela judicial efectiva, pues el Tribunal juzgador dejó de aplicar una Directiva sin justificar su decisión, con lo cual ignora los principios de primacía y efecto directo del Derecho comunitario $y$, al mismo tiempo, vulnera el artículo $24 \mathrm{CE}$. Por otro lado, se alega que el Tribunal sentenciador omitió su obligación de presentar ante el Tribunal de Justicia la cuestión prejudicial en relación al alcance e interpretación de las Directivas.

El fundamento jurídico tercero entra en la cuestión central del recurso, es decir, si la inaplicación de las Directivas supone vulneración de un derecho fundamental. Para resolver este problema se remite a la jurisprudencia sentada por este mismo Tribunal en la Sentencia 64/1991, según la cual no corresponde al Tribunal Constitucional controlar la adecuación de la actividad de los poderes públicos nacionales al Derecho comunitario. Este control corresponde a los órganos de la jurisdicción ordinaria, y en su caso, al Tribunal de Justicia. La tarea de garantizar la recta aplicación del Derecho comunitario por los poderes públicos nacionales es, pues, una cuestión excluida del recurso de amparo. Por tanto, este conflicto también es calificado como un conflicto de normas no constitucionales. De todo ello se deduce que "la aplicación por la Sentencia impugnada de determinadas normas nacionales sin aplicar de forma directa otras normas de Derecho comunitario, que los actores entienden aplicable al caso, constituye, como tal, una cuestión de legalidad ordinaria que corresponde decidir exclusivamente al órgano jurisdiccional».

Sin embargo, existe un Voto Particulra a dicha sentencia, en virtud del cual se manifiesta que la Sentencia impugnada no ha aclarado la cuestión central del debate, pues en el caso de que el Tribunal juzgador decidiera no aplicar la Directiva, debería haber alegado las razones que le han llevado a esta inaplicación.

Como vemos, el Tribunal Constitucional se declara incompetente para resolver el eventual conflicto entre la norma comunitaria y la norma interna. Esta misma línea de actuación se mantiene en las sucesivas Sentencias en las que el Alto Tribunal se ocupa de las relaciones entre el Derecho comunitario y el Derecho interno. La argumentación es clara e irrefutable: la supuesta contradicción entre la norma comunitaria y las disposiciones nacionales posteriores no es una cuestión que afecte a la constitucionalidad de estas úl- 
recho comunitario, tal como propugnaba la jurisprudencia del Tribunal de Justicia. Ello supondría el establecimiento a nivel comunitario de un marco de protección máximo de las libertades públicas, integrado por las particularidades de los Estados miembros y completado por el conjunto de principios y valores superiores -comunes a todos los ordenamientos nacionales, a los principios generales del Derecho comunitario y a las Declaraciones Internacionales sobre derechos humanos-. Sólo de esta forma puede establecerse un marco adecuado de protección de los derechos y libertades individuales, al tiempo que se estará en condiciones de evitar eventuales conflictos entre la normativa comunitaria $y$ las Constituciones de los Estados miembros. 